\title{
Comparative mycological analysis of spices used in meat industry
}

\author{
Janković Vesna , Borović Branka ${ }^{I}$,Velebit Branko ${ }^{I}$, Mitrović Radmilal, Lakićević Brankical, Spirić Danka ${ }^{l}$, \\ Baltić Tatjana ${ }^{l}$
}

A b s tra c t: Spices are often considered as one of the possible sources of meat products contamination with toxigenic moulds. Since spices are possible source of contamination of the final product and potential producers of mycotoxins, it is necessary to estimate the degree of moulds contamination. Therefore it is necessary to conduct an adequate and continuous control of spices on presence of the moulds. The choice of a culture media to carry out mycological analysis of food is extremely important to guarantee the reliability of the analysis. This paper presents an overview of the analysis of different spices $(n=15)$ for the presence of xerophilic moulds, by using Dichloran Rose-Bengal Chloramphenicol Agar" (Oxoid, CM 727) and "Dichloran-Glycerol (DG18) Agar Base" (Oxoid, CM 729)., Black and white grounded pepper, were the most contaminated (3.62-3.79 $\log _{10} \mathrm{cfu} / \mathrm{g}$ ) of 15 samples tested, while in the remaining samples an average contamination level of $2.7 \log _{10} \mathrm{cfu} / \mathrm{g}$ was established.

Key words: $a_{n}$, selective medium, xerophilic moulds.

\section{Introduction}

Spices and herbs are valued for their distinctive flavours, colours, and aromas and are among the most versatile and widely used ingredients in food preparation (Škrinjar et al., 2012). Modern meat industry cannot be imagined without utilization of spices. However, spices, together with all other dried material of herbal origin, are never sterile. As is the case with many other agricultural products, spices and herbs may be exposed to a wide range of microbial contamination pre - and post harvest (Hashem and Alamri, 2010). In most cases, they contain sporogenic bacteria and moulds. These microorganisms can cause spoilage of the product by their metabolic activity, consequently resulting in significant economic losses.

Presence of moulds in spices and later in sausages or other meat products can result in production of toxic metabolites - mycotoxins independent of contamination degree (Kocić-Tanackov et al., 2007). Mycotoxins are fungal secondary metabolites identified in many agricultural products screened for toxigenic moulds (Clevsrton and Ljunggren, 1985). Mycotoxins have been reported to be carcinogenic, teratogenic, tremorogenic, hemorrhagic, and dermatitic to a wide range of organisms, and known to cause hepatic carcinoma in man in humans and animals (Frisvad et al., 2005; Zinedine et al., 2006). Production of toxins primarily depends on genetic factors; however, environmental conditions at the site of mould growth (temperature, water activity, matrix composition, moisture content, $\mathrm{pH}$ of the medium, contamination and physical destruction of the substrate, antifungal properties and other factors) are considered highly significant (Škrinjar et al., 2012).

It has been reported that principal contaminants of spices are xerophilic moulds from the genera $E u$ rotium, Aspergillus and Penicillium (Dimić and Škrinjar, 1995; Dimić et al., 2000; Romagnoli et al., 2007). Enumeration of yeasts and filamentous fungi usually involves the inoculation of samples in solid culture media through surface or pour plate method (Beuchat and Hocking,1990; Beuchat, 1998). In general, culture media for fungal evaluation need to be highly selective, suppressing the fast growing bacterial contamination (Askun et al., 2007) and limiting the growth rate and spread of fungal colonies, but should allow the enumeration of theoretically all species present in the samples. More recently, media supplemented with antibiotics, as the dichloran rose of bengal and chloramphenicol (Škrinjar et al., 2012), emerged as more efficient alternative. These media show less toxic effect to the damaged cells,

${ }^{1}$ Institute of Meat Hygiene and Tecgchnology, Kaćanskog 13, 11000 Belgrade, Republic of Serbia.

Corresponding author: Janković Vesna, vessna@inmesbgd.com 
they are more effective to inhibit the bacterial development and are used to induce a smaller amount of food particles precipitation due its higher $\mathrm{pH}$ (Medina et al., 2005). Routinely, dichloran rose of bengal has been successfully applied to control the rate dissemination of fungal species, limiting the rapid spread of zygomycetes on the plate surface (Pardo et al., 2006). Later, media with reduced activity of water $\left(\mathrm{a}_{\mathrm{w}}\right)$ were introduced, as the dichloran glycerol agar $18 \%\left(\mathrm{a}_{\mathrm{w}} 0.95\right)$, for a general quantification of moderately xerophilic fungi, those with fastidious growth, which in a medium with traditional activity of water $\left(a_{w} 0.99\right)$ may have their growth inhibited due to the rapid development of other species.

In this paper, the efficacy of these two culture media for quantification of fungi from different spices was evaluated.

\section{Materials and methods}

\section{Samples}

A total of fifteen $(n=15)$ samples of commercially available spices were analyzed for mould contamination. The samples were provided from the health food stores in bulk and from supermarkets.

\section{Methods}

The samples were processed according to the ISO 21527-1:2008 and ISO 21527-2:2008 methods. All analyses were performed in triplicate under aseptic conditions. Samples were inoculated by surface plate technique according to the dilution performed. For surface plating, $0.1 \mathrm{~mL}$ aliquots were inoculated in plates with solidified medium, spreading the inoculum on media surface. For the enumeration, two different selective media were used: dichloran 18\% glycerol (DG18) agar and dichloran RoseBengal chloramphenicol (DRBC) agar. The plates were incubated at $28^{\circ} \mathrm{C}$ for 5-7 days and examined for presence of moulds. The results were expressed as colony forming unit per sample gram (CFU/g).

\section{Identification of the isolates}

For the identification of the cultures, each isolate was inoculated on Czapek-Dox Agar (CZ, Oxoid CM97). Macroscopic and microscopic morphological characteristics were used in the identification process. Colony colour, texture and diameter, the production of diffusible pigments, and exudates were among macroscopic features, while conidia and conidiophore arrangements were the microscopic ones.
Isolates were identified according to standard mycological procedures (Pitt and Hocking, 1995; Samson and Pitt., 2000).

\section{Results and discussion}

Table 1 shows the results of mycological analyses - enumeration of moulds in 15 different spice samples using two different selective media, DG18 and DRBC. These media have different composition of added sugars and water activity $\left(\mathrm{a}_{\mathrm{w}}\right)$. Numerous xerophilic moulds, which are carriers of spices contamination, have optional $\mathrm{a}_{\mathrm{w}}$ below 0.90 . Collaborative investigations using those two selective media provide more accurate perspective on micro populations. From fifteen spices, all samples were with growth (Table 1), while samples 5 and 6 had the highest contamination level (3.62-3.79 $\left.\log _{10} \mathrm{cfu} / \mathrm{g}\right)$. Generally, the moulds were found with the mean concentration of $2.7 \log _{10} \mathrm{cfu} / \mathrm{g}$.

DG18, of all the media evaluated, showed better efficacy of fungal contamination in spices used in meat industry. DG18 presented the better results in the quantity from the evaluated spices.

Isolated moulds were classified into four genera (Aspergillus, Alternaria, Paecylomyces and Penicillium). Considering DG18, mycological research showed better fungal diversity and the dominant presence of genus Aspregillus (47.82\%). The remaining moulds were from genus Penicillium (39.13\%), Paecylomyces (8.69\%), and Alternaria (4.34\%). On DRBC, contamination level was the same for Aspergillus spp. and Penicillium spp. (Table 2). In addition, the number of different genera present was greater on the DG18 agar plates than on the DRBC plates.

Dichloran 18\% glycerol (DG18) agar was originally developed to enumerate xerophilic foodborne moulds. However, some laboratories are using DG18 agar as a general medium to enumerate foodborne moulds and yeasts. These results pointed to the fact that media with limited amount of free water suppressed the growth of moulds that are not extremely xerophilic in nature. It is also known that xerophilic moulds can be divided into fast-growing and slow-growing forms (Kocic-Tanackov et al., 2007). Slow-growing moulds, even under optimal conditions can be overgrown by fast-growing xerophiles. The emergence of Aspergilli and Penicillia species on the two different media indicated the presence of these moulds as the dominant mycoflora of different spices. This observation was greatly in agreement with other authors who studied mycoflora of spices 
Table 1. Average total count of moulds obtained by different culture media in spices

Tabela 1. Prosečne vrednosti ukupnog broja plesni utvrđene u začinima korišćenjem različitih podloga

\begin{tabular}{|c|c|c|}
\hline \multirow{2}{*}{ Sample } & \multicolumn{2}{|c|}{ total count $\left(\log _{10} \mathrm{cfu} / \mathrm{g}\right)$} \\
\hline & $\begin{array}{l}\text { DG18 } \\
\text { DG18 }\end{array}$ & DRBC \\
\hline 1. Clove/Karanfilić & 2.95 & 2.93 \\
\hline 2. Rosemary/Ruzmarin & 2.30 & 2 \\
\hline 3. Sesame/Susam & 2.20 & 2 \\
\hline 4. Ginger/Đumbir & 2.50 & 2.41 \\
\hline 5. White pepper - ground/Mleveni beli biber & 3.79 & 3.77 \\
\hline 6. Black pepper - ground/Mleveni crni biber & 3.66 & 3.62 \\
\hline 7. White pepper in grain/Beli biber u zrnu & 2.51 & 3.46 \\
\hline 8. Black pepper in grain/Crni biber u zrnu & 3.62 & 3.70 \\
\hline 9. Oregano/Origano & 2 & 2 \\
\hline 10. Caraway/Kim & 3.54 & 3.46 \\
\hline 11. Chilli/Čili & 2.51 & 2.49 \\
\hline 12. Curry/Kari & 3.55 & 3.49 \\
\hline 13. Thyme/Timijan & 2.34 & 2.32 \\
\hline 14. Bay leaf/Lovorov list & 2 & 2 \\
\hline 15. Sweet basil/Bosiljak & 2.07 & 2 \\
\hline
\end{tabular}

and medicinal herbs (Dimić et al., 2008; Janković et al., 2008; Škrinjar et al., 2012).

The variation in frequency of mycopopulation of spices cultivated on DG18 and DRBC media is most probably related to the strain type within one species. Environmental factors also have significant effect and can induce the growth of mycopopulation on lower $\mathrm{a}_{\mathrm{w}}$ values (optimal temperature and type of nutritive components in the medium). Xerophiles, especially selective ones tend to be very sensitive on environmental conditions.

Askun et al. (2007) used Rose-Bengal chloramphenicol Agar (Oxoid, CM 549) and Dichloran-Glycerol (DG18) Agar (Oxoid, CM 729) for determination of xerophilic moulds. Other media can also be used such as Dichloran-Glycerol (DG18)
Agar Base (Pitt and Hocking, 1985), MY70FG and MY50FG (Beuchat, 1998), MY50S and MY40S (Beuchat and Hocking, 1990).

Moulds fall into two ecological categories, e.g., field and storage moulds. Field moulds were observed to invade developing or mature seeds while they are on the plant, the major field moulds genera being Alternaria, Fusarium and Cladosporium. On the other hand, storage moulds are those encountered on plants in conditions of moisture commonly found in stored products. These moulds principally belong to species Aspergillus and Penicillium (Abou Donia, 2008). The spices can undergo fungal contamination mainly during spice processing, storage and transport (Dimić et al., 2008). 
Table 2. Review of moulds genera isolated from spices

Tabela 2. Pregled izolovanih rodova plesni iz začina

\begin{tabular}{|c|c|c|}
\hline \multirow{2}{*}{ Sample } & \multicolumn{2}{|c|}{ Genus } \\
\hline & DG18 & DRBC \\
\hline 1. Clove/Karanfilić & $\begin{array}{l}\text { Aspergillus spp., } \\
\text { Penicillium spp. }\end{array}$ & $\begin{array}{l}\text { Aspergillus spp., } \\
\text { Penicillium spp. }\end{array}$ \\
\hline 2. Rosemary/Ruzmarin & $\begin{array}{l}\text { Aspergillus spp., } \\
\text { Penicillium spp. }\end{array}$ & Penicillium spp. \\
\hline 3. Sesame/Susam & Penicillium spp. & Penicillium spp. \\
\hline 4. Ginger/Đumbir & $\begin{array}{l}\text { Aspergillus spp., } \\
\text { Penicillium spp. }\end{array}$ & $\begin{array}{l}\text { Aspergillus spp., } \\
\text { Penicillium spp. }\end{array}$ \\
\hline 5.White pepper ground/Mleveni beli biber & $\begin{array}{l}\text { Aspergillus spp., } \\
\text { Penicillium spp. }\end{array}$ & $\begin{array}{l}\text { Aspergillus spp., } \\
\text { Penicillium spp. }\end{array}$ \\
\hline 6. Black pepper ground/Mleveni crni biber & $\begin{array}{l}\text { Aspergillus spp., } \\
\text { Paecylomyces spp. }\end{array}$ & Aspergillus spp. \\
\hline 7. White pepper grain/Beli biber u zrnu & $\begin{array}{l}\text { Aspergillus spp., } \\
\text { Penicillium spp. }\end{array}$ & Penicillium spp. \\
\hline 8. Black pepper grain/Crni biber u zrnu & Aspergillus spp & Aspergillus spp \\
\hline 9. Oregano/Origano & $\begin{array}{l}\text { Aspergillus spp., } \\
\text { Alternaria spp. }\end{array}$ & Aspergillus spp., \\
\hline 10. Caraway/Kim & Penicillium spp. & Penicillium spp. \\
\hline 11. Chilli/Čili & Aspergillus spp & Aspergillus spp \\
\hline 12. Curry/Kari & Aspergillus spp & Aspergillus spp \\
\hline 13. Thyme/Timijan & Penicillium spp. & Penicillium spp. \\
\hline 14. Bay leaf/Lovorov list & $\begin{array}{l}\text { Aspergillus spp., } \\
\text { Alternaria spp. }\end{array}$ & $\begin{array}{l}\text { Aspergillus spp., } \\
\text { Alternaria spp. }\end{array}$ \\
\hline 15. Sweet basil/Bosiljak & Penicillium spp. & Penicillium spp. \\
\hline
\end{tabular}

\section{Conclusion}

Based on obtained results, it can be concluded that it is necessary to use different selective media adjusted to specific requirements of xerophiles in order to achieve proper isolation and accurate contamination degree of spices by xerophilic moulds.
Utilization of selective media enables acquiring representative insight into spices mycopopulation.

Our investigation showed that DG18, of all the media evaluated, showed better efficacy in determination and enumeration of moulds in spices, fungal diversity and the dominant presence of genus Aspergillus $(47.82 \%)$ in spices used in meat industry. 


\section{References}

Abou Donia, M. A., 2008. Microbiological quality and aflatoxinogenesis of Egyptian spices and medicinal plants. Global Vetereinarian, 2,4, 175-181.

Askun T., Eltem R., Eltem E., 2007. Comparison of Rose-Bengal chloramphenicol agar and dichloran glycerol agar (DG18) for Enumeration and Isolation of Moulds from Raisins. Journal of Applied Biological Sciences 1, 2, 71-75.

Beuchat L. R., 1998. Progress in conventional methods for detection and enumeration of foodborne yeasts. Food Technology and Biotechnlogy, 36, 267-272.

Beuchat L. R., Hocking A. D., 1990. Some considerations when analysing foods for the presence of xerophilic fungi. Journal of Food Protection, 53, 984-989.

Clevsrton G., Ljunggren H., 1985. Aflatoxin formation and the dual phenomenon. Mycopathologia 92,129-139.

Dimić G., Škrinjar M., 1995. Toksigene plesni i mikotoksini u začinskim smešama i biberu u zrnu korisćenim u industriji mesa. Tehnologija mesa, 5, 302-305.

Dimić G., Škrinjar M., Došen-Bogićević V., 2000. Plesni, potencijalni proizvođač sterigmatocistina u začinima. Tehnologija mesa, 41, 4-6, 131-137.

Dimić G. R., Kocić - Tanackov S. D., Tepić A. N., Vujičić B. L., Šumić Z. M., 2008. Mycopopulation of spices. BIBLID 39, 1-9.

Frisvad C. J., Skouboe P., Samson A. R., 2005. Taxonomic comparison of three different groups of aflatoxin producers and new efficient producer of aflatoxin B1, sterigmatocystine and 3-Omethylsterigmatocystine, Aspergillus rumbellisp. nov. Systematic and Applied Microbiology, 28, 442-453.

Hashem M., Alamri S., 2010. Contamination of common spices in Saudi Arabia markets with potential mycotoxin-producing fungi. Saudi Journal of Biological Sciences, 17, 167-175.

ISO 21527 - Microbiology of food and animal feeding stuffs - Horizontal method for the enumeration of yeasts and moulds - Part 2: Colony count technique in products with water activity less than or equal to 0,95 .

Janković V., Škrinjar M., Vukojević J., Borović B., Radmili M., 2008. Izolovanje i identifikacija kserofilnih plesni iz začina koji se koriste u industriji mesa. Tehnologija mesa, $49,1-2,30-35$.

Kocić-Tanackov, S. D., Dimić, G. R., Karali, D., 2007. Contamination of spices with moulds potential producers of sterigmatocystine. APTEFF 38, 29-35.

Medina A., Mateo R., Lopez-Ocana L., Manuel Valle-Algarra F., Jimenez M., 2005. Study of Spanish Grape Mycobiota and Ochratoxin Isolates of Aspergillus tubingensis and Other Aspergillus Section Nigri. Applied and Environmental Microbiology, 71, 4696-4702.

Pardo E., Sanchis V., Ramos A. J., Marín S., 2006. Non-specificity of nutritional substrate for ochratoxin A production by isolates of Aspergillus ochraceus. Food Microbiology, 23, 351-358.

Pitt J. I., Hocking A. D., 1985. Fungi and food spoilage. CSIRO Division of Food Research, Academic Press, Sidney.

Romagnoli B., Menna V., Gruppioni N., Bergamini C., 2007. Aflatoxins in spices, aromatic herbs, herbs-teas and medicinal plants marketed in Italy. Food Control 18, 697-701.

Samson R. A., Pitt J. I., 2000. Integration of Modern Taxonomic Methods for Penicillium and Aspergillus Classification. Harwood academic publishers, Amsterdam.

Škrinjar M., Janković V., Vesković Moračanin S., Vukojević J., 2012. Xerophilic moulds isolated from spices used in meat industry as potential producers of mycotoxins. Zbornik Matice srpske za prirodne nauke, 123, 7-16.

Zinedine A., Brera C., Elakhdari S., Catano C., Debegnach F., Angelini S., De Santis B., Faid M., Benlemlih M., Minardi V., Miraglia M., 2006. Natural occurrence of mycotoxins in cereals and spices commercialized in Morocco. Food Control 17, 868-874. 


\title{
Komparativna mikološka analiza začina koji se koriste u industriji mesa
}

\author{
Janković Vesna, Borović Branka, Velebit Branko, Mitrović Radmila, Lakićević Brankica, Spirić Danka, \\ Baltić Tatjana
}

R e z i m e: Jedan od mogućih izvora kontaminacije proizvoda od mesa su i začini. Kao i svi sušeni biljni materijali, začini nikada nisu sterilni. Sadrže, najčešće, sporogene bakterije i razne vrste plesni. Nezavisno od stepena kontaminacije, prisustvo plesni u začinima, a posledično i u proizvodima od mesa, pod određenim uslovima, može da dovede do sinteze toksičnih metabolita - mikotoksina. Sinteza mikotoksina uslovljena je, pre svega, genetskim faktorima, ali zavisi i od uslova spoljne sredine u kojoj se plesni razmnožavaju (temperatura, sastav supstrata, sadržaj vlage, $p H$ sredine, aktivnost slobodne vode - $a_{w}$ prisustvo antifungalnih komponenti itd.).

Kao glavni kontaminenti začina navode se kserofilne vrste plesni, sa rodovima Eurotium, Aspergillus i Penicillium kao predstavnicima. S obzirom na to da začini predstavljaju potencijalni izvor kontaminacije proizvoda od mesa, cilj rada je bio da se utvrdi stepen rasprostranjenosti određenih vrsta plesni korišćenjem različitih selektivnih podloga.

Zbog činjenice da ne postoje odgovarajuće mikrobiološke podloge koje bi bile pogodne, istovremeno, za rast $i$ određivanje „umereno" $i$,,ekstremno" kserofilnih vrsta plesni, neophodno je kombinovanje selektivnih podloga kod kojih je a $a_{w}$-vrednost znatno redukovana. Korišćenjem dve selektivne podloge DG 18 i DRBC, a u cilju izolovanja i utvrđivanja ukupnog broja plesni u začinima $(n=15)$, dobijeni su rezultati koji su dali preporuku za njihovu dalju primenu u sličnim ispitivanjima. Izolovane plesni klasifikovane su u četiri roda: Aspergillus, Alternaria, Paecylomyces i Penicillium. Na osnovu mikoloških istraživanja, DG18 podloga pokazala je izraženiji diverzitet $i$ veći stepen efikasnosti u detekciji Aspergillus vrsta (47,82\%). Preostale plesni pripadale su rodovima Penicillium (39,13\%), Paecylomyces (8.69\%) i Alternaria (4,34\%). Za DRBC podlogu, utvrđen je isti nivo kontaminacije za Aspergillus spp. $i$ Penicillium spp. Na osnovu dobijenih rezultata, može se zaključiti da je, u cilju izolovanja i utvrđivanja realne mikopopulacije plesni u začinima, neophodna primena selektivnih podloga koje su prilagođene specifičnim svojstvima ispitivanih kserofila.

Ključne reči: $a_{w}$, selektivne podloge, kserofilne plesni.

Paper received: 16.09 .2013 .

Paper accepted: 19.09.2013. 